\title{
A Retrospective Renal Study from a Lupus Vasculitis Clinic
}

\author{
Gaurav Singh1, Lauren White², Patrick Flynn², Sajan Thomas³, Lakshmanan Jeyaseelan4, \\ Mani Thenmozhi', George John ${ }^{3}$, Paul Kubler5, Dwarakanathan Ranganathan ${ }^{3 *}$ \\ ${ }^{1}$ Department of Internal Medicine, Princess Alexandra Hospital, Brisbane, Australia \\ 2Department of Internal Medicine, Royal Brisbane and Women's Hospital, Brisbane, Australia \\ ${ }^{3}$ Department of Nephrology, Royal Brisbane and Women's Hospital, Brisbane, Australia \\ ${ }^{4}$ Department of Biostatistics, Christian Medical College, Vellore, India \\ ${ }^{5}$ Department of Rheumatology, Royal Brisbane and Women's Hospital, Brisbane, Australia \\ Email: gaurav063@hotmail.com, laurensue.white@gmail.com, patrick.flynn@uqconnect.com.au, \\ docsajan11@gmail.com, ljey@hotmail.com, mani.thenmozhi@gmail.com, george.john@health.qld.gov.au, \\ paul.kubler@health.qld.gov.au, ${ }^{*}$ Dwarakanathan.Ranganathan@health.qld.gov.au
}

Received 29 June 2015; accepted 18 August 2015; published 21 August 2015

Copyright (C) 2015 by authors and Scientific Research Publishing Inc.

This work is licensed under the Creative Commons Attribution International License (CC BY).

http://creativecommons.org/licenses/by/4.0/

(c) (i) Open Access

\section{Abstract}

Aim: In July 2009, a combined Renal Rheumatology Lupus Vasculitis (RRLV) clinic, the first of its kind for adult patients in Australia, was started at Royal Brisbane \& Women's Hospital. This is an audit of progression of renal disease to assess if patients attending this clinic had comparable results to published studies of similar cohorts with lupus Nephritis (LN) and vasculitis. Methods: We conducted a retrospective audit of all the patients who attended this clinic from July 2009 to October 2013. There were 33 patients followed up in the vasculitis group and 36 in the LN group. Patients with other connective tissue disorders were excluded from the analysis as the numbers were insignificant. Results: The mean estimated glomerular filtration rate of vasculitis and LN patients improved from 32.06 to $45.82 \mathrm{ml} / \mathrm{min} / 1.73 \mathrm{~m}^{2}$ and 62.42 to $65.53 \mathrm{ml} / \mathrm{min} / 1.73 \mathrm{~m}^{2}$ respectively. The mean urine protein/creatinine ratio of vasculitis and $\mathrm{LN}$ patients improved from 420 to 85 and 406 to 70 respectively. No patients died in either group. One vasculitis and two LN patients required maintenance dialysis. Three $L N$ patients underwent renal transplantation. Conclusion: The results show excellent patient and renal survival and support the concept of a combined renal rheumatology clinic in managing renal disease from systemic connective tissue disorders.

\section{Keywords}

Vasculitis, Lupus Nephritis, Survival, Estimated Glomerular Filtration Rate, Urinary Protein

\footnotetext{
${ }^{*}$ Corresponding author.
}

How to cite this paper: Singh, G., White, L., Flynn, P., Thomas, S., Jeyaseelan, L., Thenmozhi, M., John, G., Kubler, P. and Ranganathan, D. (2015) A Retrospective Renal Study from a Lupus Vasculitis Clinic. Open Journal of Nephrology, 5, 75-82. 


\section{Creatinine Ratio}

\section{Introduction}

Renal involvement occurs in many autoimmune connective tissue disorders (CTD). Impairment of renal function varies from 50\% in Systemic Lupus Erythematosus (SLE) and vasculitis, 5\% in Scleroderma, and rarely in Sjogren's syndrome or anti-phospholipid antibody syndrome [1]. The involvement can progress to end stage renal disease (ESRD) [2] [3] reducing life expectancy compared to general population [4] [5].

Patients with CTDs have multi-system involvement and need care from Rheumatology and Renal Medicine. There are a few combined Lupus Vasculitis clinics in UK, USA, and for children, in Australia [6]-[8]. A Renal Rheumatology Lupus Vasculitis Clinic (RRLV) was started at Royal Brisbane and Women's Hospital (RBWH) in July 2009.

The patients in this clinic were managed as per international guidelines (Tables 1-3) and detailed records on patient progress were maintained [9]-[18]. Patient survival and progression of kidney disease were measured as key performance indicators.

We conducted a retrospective audit of progression of renal disease in patients attending the combined RRLV clinic to establish whether patients followed up in this clinic had comparable patient and renal survival rates with published reports of cohorts with lupus Nephritis (LN) and vasculitis.

Table 1. Standard therapy used for treatment of renal vasculitis [9] [13]-[15] [18].

\begin{tabular}{|c|c|c|c|}
\hline Induction therapy & & DOSE & Comments \\
\hline \multirow[t]{2}{*}{ Methylprednisolone then prednisolone } & $\begin{array}{l}\text { IV } \\
\text { PO }\end{array}$ & $\begin{array}{l}\text { MP } 500 \text { - } 750 \mathrm{mg} \times 3 \text { consecutive } \\
\text { days then prednisone } 1 \mathrm{mg} / \mathrm{kg} / \text { day } \\
\text { not exceeding } 75 \mathrm{mg} \text {; tapered after a } \\
\text { few weeks to lowest effective dose }\end{array}$ & \multirow[t]{3}{*}{ Usually 3 - 6 months } \\
\hline & Plus & & \\
\hline Cyclophosphamide-First Option & IV & $\begin{array}{c}\text { Refer Table 2, } 6 \text { - } 12 \text { infusions, } \\
\text { 3 - } 6 \text { months }\end{array}$ & \\
\hline \multirow[t]{2}{*}{ Rituximab-Second Option } & IV & $375 \mathrm{mg} / \mathrm{m}^{2} \times 4$ doses & \multirow[t]{2}{*}{$\begin{array}{l}\text { Cannot tolerate or not } \\
\text { responding to IV Cyclophosphamide }\end{array}$} \\
\hline & Plus & & \\
\hline Plasma Exchange & & 7 exchanges in 2 weeks & $\begin{array}{l}\text { Pulmonary Haemorrhage and } \\
\text { or severe renal insufficiency }\end{array}$ \\
\hline Maintenance Therapy & Plus & & \\
\hline Prednisolone & PO & tapering dose-till 5 - 7 mg/daily & \multirow{4}{*}{ Usually 18 months since remission } \\
\hline Azathioprine-First Option & $\mathrm{PO}$ & 1 - 3 mg/kg/day & \\
\hline MMF Second Option & $\mathrm{PO}$ & 1 - 1.5 gm twice daily & \\
\hline MPS-Second Option & $\mathrm{PO}$ & 720 - 1080 mg twice daily & \\
\hline
\end{tabular}

IV, intravenous; PO, per os (oral administration); MP, Methylprednisone; MPS, Mycophenolate Sodium; MMF, MycophenolateMoeftil.

Table 2. Cyclophosphamide dose adjustment according to age and renal function [9] [10].

\begin{tabular}{ccc}
\hline Age (years) & Cyclophosphamide dose reduction (per pulse, $\mathrm{mg} / \mathrm{kg}$ ) IV Mesna given to minimize toxicity \\
\hline$<60$ & eGFR $>30 \mathrm{ml}$ & eGFR $<30 \mathrm{ml}$ \\
$60-70$ & 15 & 12.5 \\
$>70$ & 12.5 & 10 \\
\hline
\end{tabular}

IV, intravenous. 
Table 3. Standard therapy used for treatment of Lupus Nephritis [10]-[12] [17].

\begin{tabular}{|c|c|c|c|}
\hline Induction therapy & & DOSE & Comments \\
\hline \multirow[t]{2}{*}{ Methylprednisolone then prednisolone } & $\begin{array}{l}\text { IV } \\
\text { PO }\end{array}$ & $\begin{array}{l}\text { MP } 500-750 \mathrm{mg} \times 3 \text { days then } \\
\text { prednisone } 0.5-1 \mathrm{mg} / \mathrm{kg} / \mathrm{day} \text { to a } \\
\text { maximum of } 60 \mathrm{mg} \text { tapered after a few } \\
\text { weeks to lowest effective dose }\end{array}$ & Usually 3 - 6 months \\
\hline & Plus & & \\
\hline MPS-First option & $\mathrm{PO}$ & 720 - 1080 mg twice daily & \\
\hline IV Cyclophosphamide Second option & IV & $500 \mathrm{mg}$ IV once in 2 weeks $\times 6$ & $\begin{array}{l}\text { Cannot tolerate or not } \\
\text { responding to MPS }\end{array}$ \\
\hline Maintenance Therapy & Plus & & \\
\hline Prednisolone & $\mathrm{PO}$ & slow tapering dose to 5 - $7 \mathrm{mg}$ & \\
\hline MPS or MMF-First option & $\mathrm{PO}$ & MPS-720 mg twice daily/MMF 1 gm bid & \\
\hline \multirow[t]{2}{*}{ Azathioprine-Second Option } & PO & 1 - 2 mg/kg/day & Usually 18 months since remission \\
\hline & & Plus & \\
\hline Hydroxychloroquine & $\mathrm{PO}$ & 400 mg daily & \\
\hline
\end{tabular}

IV, intravenous; PO, per os (oral administration); MP, Methylprednisolone; MPS, Mycophenolate Sodium; MMF, Mycophenolate Moeftil.

\section{Methods}

This is an audit of all patients who attended this clinic from July 2009 to October 2013. They were grouped based on renal involvement with vasculitis or LN and analyzed separately as the reported survival rates are different [2] [3]. Other CTDs were excluded from the analysis as the numbers were small.

We studied trends in estimated glomerular filtration rate (eGFR), urine protein creatinine ratio (uPCR), patient and renal survival.

\section{Data}

Data collected from medical records included age, gender, cause of renal involvement, renal biopsy, pulmonary involvement and requirement of plasmapheresis and dialysis, were de-identified and recorded on a spread sheet.

Investigations included full blood examination, renal function tests, urine microscopy, uPCR, disease markers of vasculitis i.e. perinuclearantineutrophil cytoplasmic antibodies (P-ANCA) and cytoplasmic ANCA(C-ANCA) titres, anti-proteinase3 (PR3), myeloperoxidase (MPO) antibodies and disease markers of LN i.e. anti-nuclear antibodies (ANA), anti-double stranded DNA (ds-DNA) antibodies, complement (c) 3 and 4.

Laboratory test results were recorded at six monthly intervals, along with data regarding mortality, renal loss and renal replacement modalities. Duration and details of follow up at renal-rheumatology clinic were collected which included date of first visit, number of clinic visits and total duration of follow up.

\section{Statistical Methods}

Descriptive statistics and frequency distributions were done for continuous and categorical variables respectively. Associations between eGFR and risk factors were calculated by bi-variate (unadjusted) and multivariate analysis (adjusted). A generalized estimating equations (GEE) model was used to analyze repeated measures on eGFR for the same patient with population-averaged effects of covariates. Exchangeable correlation structure was used. The data were analyzed by using SPSS 16.0 for Windows.

\section{Patient Characteristics}

There were 31 patients followed up with renal vasculitis and 36 with LN. Fifteen patients with miscellaneous CTD were excluded from the analysis due to small numbers. Among these, there were sixpatients with overlap syndrome, three patients each with Sjogren's syndrome, two patients with Henoch-Schonlein purpura, and one each with scleroderma, polyarteritis nodosa, cryoglobulinemic vasculitis and primary antiphospholipid antibody syndrome.

Among vasculitis patients, the number of patients with microscopic polyangiitis (MPA), granulomatous polyan- 
giitis (GPA), anti-glomerular basement membrane (anti-GBM) disease and ANCA negative disease were 12, 8, 2 and 3 respectively. Six patients did not undergo a biopsy and there were no patients with combined ANCA and antiGBM antibodies. Among LN patients, number of patients with class I, II, III, IV and V disease on histology were 1, 3, 6, 16 and 3 respectively. Five patients did not have a biopsy and two had mixed class III and V disease on histology. The patient characteristics namely age, gender, comorbidities, organ system involvement, eGFR and uPCR at baseline and at the end of follow up, duration of disease and clinic follow up are shown in Table 4.

Table 4. Patient characteristics.

\begin{tabular}{|c|c|c|c|}
\hline & $\begin{array}{l}\text { Vasculitis } \\
(\mathrm{n}=31)\end{array}$ & $\begin{array}{c}\text { Lupus } \\
\text { nephritis }(\mathrm{n}=36)\end{array}$ & $\begin{array}{l}\text { Miscellaneous } \\
\quad(\mathrm{n}=15)\end{array}$ \\
\hline Gender: Male/Female & $16 / 15$ & $8 / 28$ & $4 / 11$ \\
\hline Age: Median (IQR) & $65(45-76)$ & $42(29-55)$ & $60(39.5-64.5)$ \\
\hline \multicolumn{4}{|l|}{ Comorbidities } \\
\hline Hypertension & 18 & 25 & 7 \\
\hline Cardiac Failure & 2 & 4 & 1 \\
\hline Ischemic heart disease & 8 & 5 & 1 \\
\hline Peripheral Vascular disease & 3 & 0 & 0 \\
\hline Stroke & 1 & 4 & 3 \\
\hline Malignancy & 4 & 2 & 3 \\
\hline Diabetes Mellitus & 4 & 2 & 1 \\
\hline Liver disease & 0 & 4 & 2 \\
\hline \multicolumn{4}{|l|}{ Organ involvement } \\
\hline Cutaneous & 1 & 30 & 5 \\
\hline Oral/nasal ulcers & 0 & 12 & 0 \\
\hline ENT & 3 & 0 & 0 \\
\hline Non scarring alopecia & 0 & 6 & 0 \\
\hline Arthritis/Arthralgia & 4 & 29 & 3 \\
\hline Serositis & 0 & 14 & 0 \\
\hline Neurological & 4 & 7 & 3 \\
\hline Hematological & 0 & 20 & 2 \\
\hline Pulmonary & 8 & 3 & 3 \\
\hline $\begin{array}{c}\text { eGFR (ml/mt/1.73m²) } \\
\text { Baseline Median (IQR) } \\
\text { End of study Median (IQR) }\end{array}$ & $\begin{array}{c}18(9-41) \\
50(24-68)\end{array}$ & $\begin{array}{c}67.5(43.5-90) \\
81.5(44-90)\end{array}$ & $\begin{array}{c}54(29.5-64.5) \\
61.5(40.5-85.5)\end{array}$ \\
\hline $\begin{array}{c}\text { Urine protein/creatinine ratio } \\
\text { Baseline Median (IQR) } \\
\text { End of study Median (IQR) }\end{array}$ & $\begin{array}{c}197(87-420) \\
54(15-147)\end{array}$ & $\begin{array}{l}85(29-462) \\
29(15-177)\end{array}$ & $\begin{array}{c}82(23.5-183.5) \\
43.5(20.5-146.5)\end{array}$ \\
\hline $\begin{array}{c}\text { Number of patients on dialysis } \\
\text { Baseline } \\
\text { End of study }\end{array}$ & $\begin{array}{l}6 \\
1\end{array}$ & $\begin{array}{l}2 \\
2\end{array}$ & $\begin{array}{l}1 \\
0\end{array}$ \\
\hline Number of renal transplants during course of study & 0 & 3 & 1 \\
\hline $\begin{array}{c}\text { Time since diagnosis (months) } \\
\text { Median (IQR) } \\
\text { Duration of follow up (months) } \\
\text { Median (IQR) }\end{array}$ & $\begin{array}{l}24(15-51) \\
21(14-45)\end{array}$ & $\begin{array}{l}52(31-62) \\
45(23-50)\end{array}$ & $\begin{array}{l}36(22-46) \\
25(14-41)\end{array}$ \\
\hline
\end{tabular}

IQR, Inter-quartile range; eGFR, estimated glomerular filtration rate. 


\section{Results}

We analyzed data from patients with renal vasculitis and LN separately. During follow up in the vasculitis patients the mean eGFR improved from 32.06 to $45.82 \mathrm{ml} / \mathrm{min} / 1.73 \mathrm{~m}^{2}$ (Figure 1(a)). The mean uPCR declined from 420 to 85 (Figure 1(b)). There were no deaths while one patient required maintenance dialysis.

We conducted a GEE analysis of the trend of eGFR in patients with vasculitis for age, gender, renal histology, and plasmapheresis (Table 5). We found a statistically significant increase in mean eGFR in males as compared to females while with ages less than or greater than 60, there was no difference. During follow up, compared to patients MPA, patients with GPA and anti-GBM disease had a statistically significant increase in mean eGFR and patients with ANCA negative vasculitis did not show a significant change. Among patients requiring plasmapheresis the mean improvement in eGFR was significantly less as compared to patents who did not receive plasmapheresis.

In the LN group the mean eGFR improved from 62.42 to $65.53 \mathrm{ml} / \mathrm{min} / 1.73 \mathrm{~m}^{2}$ (Figure 1 (c)) and the mean uPCR from 406 to 70 (Figure 1(d)). There were no deaths, but 5 patients lost kidney function with 3 receiving renal transplantation and 2, maintenance dialysis.

A GEE analysis was conducted with regards to variables including, age gender, and histology. In LN group there was no statistically significant difference in the trend in eGFR based on age less than or greater than 60 or sex (Table 5). As compared to class V LN, class I LN had a mean improvement of $19.80 \mathrm{ml} / \mathrm{min} / 1.73 \mathrm{~m}^{2}$ (P value 0.072 ) during follow up, not reaching statistical significance. Similarly there was no statistically significant difference in mean improvement in eGFR among other classes of LN.

\section{Discussion}

We compared results of our study with published data on patient survival and surrogate markers including renal
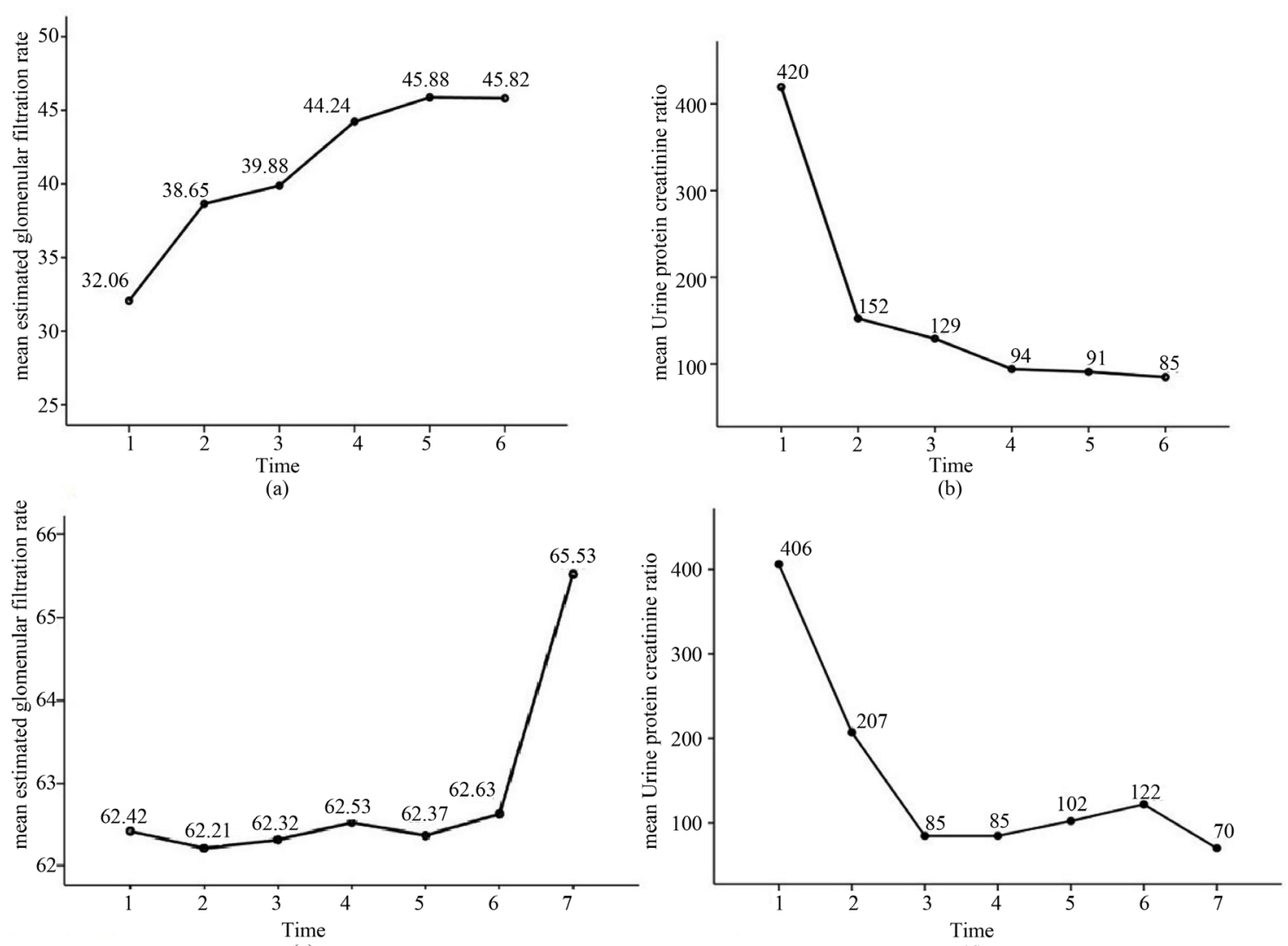

(c)

(d)

Figure 1. Profile plots for mean estimated glomerular filtration rate and mean urine protein creatinine ratio during follow up in vasculitis (a) and (b) and Lupus Nephritis (c) and (d). Time measured in 6 month intervals. 
Table 5. GEE analysis for vasculitis and LN group of Patients eGFR over a time ( $0^{\mathrm{a}}$ used for comparison variable).

\begin{tabular}{|c|c|c|c|c|}
\hline \multirow{2}{*}{ Variables } & \multirow{2}{*}{ Coefficient } & \multicolumn{2}{|c|}{ 95\% Wald Confidence Interval } & \multirow{2}{*}{$P$ value } \\
\hline & & Lower & Upper & \\
\hline \multicolumn{5}{|c|}{ Vasculitis group of patients } \\
\hline $\begin{array}{l}\text { Age } \\
\leq 60 \\
>60\end{array}$ & $\begin{array}{c}7.03 \\
0^{\mathrm{a}}\end{array}$ & -6.02 & 20.07 & 0.291 \\
\hline $\begin{array}{l}\text { Gender } \\
\text { Male } \\
\text { Female }\end{array}$ & $\begin{array}{c}15.53 \\
0^{\mathrm{a}}\end{array}$ & 2.45 & 28.62 & 0.020 \\
\hline $\begin{array}{c}\text { Histology } \\
\text { No Biopsy } \\
\text { Anti GBM } \\
\text { GPA } \\
\text { ANCA Negative } \\
\text { MPA }\end{array}$ & $\begin{array}{c}5.01 \\
32.96 \\
18.93 \\
-2.28 \\
0^{\mathrm{a}}\end{array}$ & $\begin{array}{c}-11.61 \\
0.40 \\
1.65 \\
-14.25\end{array}$ & $\begin{array}{c}21.63 \\
65.51 \\
36.22 \\
9.68\end{array}$ & $\begin{array}{l}0.555 \\
0.047 \\
0.032 \\
0.708\end{array}$ \\
\hline $\begin{array}{c}\text { Plasmapheresis } \\
\text { Yes } \\
\text { No }\end{array}$ & $\begin{array}{c}-16.61 \\
0^{\mathrm{a}}\end{array}$ & -31.13 & -2.10 & 0.025 \\
\hline Time & 0.38 & -1.42 & 2.19 & 0.677 \\
\hline \multicolumn{5}{|c|}{ LN group of patients } \\
\hline $\begin{array}{l}\text { Age } \\
\leq 60 \\
>60\end{array}$ & $\begin{array}{c}5.51 \\
0^{\mathrm{a}}\end{array}$ & -20.46 & 31.49 & 0.677 \\
\hline $\begin{array}{c}\text { Gender } \\
\text { Male } \\
\text { Female }\end{array}$ & $\begin{array}{c}4.47 \\
0^{\mathrm{a}}\end{array}$ & -16.21 & 25.15 & 0.672 \\
\hline $\begin{array}{l}\text { Histology } \\
\text { Class } 1 \\
\text { Class } 2 \\
\text { Class } 3 \\
\text { Class } 4 \\
\text { Class } 5\end{array}$ & $\begin{array}{c}19.80 \\
-5.09 \\
2.65 \\
-9.96 \\
0^{\mathrm{a}}\end{array}$ & $\begin{array}{c}-1.81 \\
-43.07 \\
-24.07 \\
-33.76\end{array}$ & $\begin{array}{l}41.40 \\
32.90 \\
29.36 \\
13.84\end{array}$ & $\begin{array}{l}0.072 \\
0.793 \\
0.846 \\
0.412\end{array}$ \\
\hline $\begin{array}{l}\text { Dialysis } \\
\text { Yes } \\
\text { No }\end{array}$ & $\begin{array}{c}-29.61 \\
0^{\mathrm{a}}\end{array}$ & -46.70 & -12.53 & 0.001 \\
\hline Time & 0.27 & -1.88 & 2.42 & 0.807 \\
\hline
\end{tabular}

LN, Lupus Nephritis; eGFR, Estimated glomerular filtration rate; Anti GBM, Anti glomerular basement membrane disease; GPA, Granulomatosis with Polyangitis; ANCA, Antineutophil Cytoplamic Antibody; MPA, Microscopic Polyangitis.

survival, trend in eGFR and uPCR for vasculitis and LN patients respectively.

In a study of 273 ANCA vasculitis patients, survival rates at 1, 5 and 10 years were $90 \%, 83 \%$ and $74 \%$ respectively, similar to results from previous studies [2] [19]. At presentation 48\% required dialysis, and among those who were independent of dialysis 7\% developed ESRD [2]. In our clinic during 4 years of follow up, one patient with vasculitis required maintenance dialysis while none died.

In a study involving 491 patients with LN, the overall cumulative probability of survival at 1, 5, 10 and 20 years was $98 \%, 88 \%, 77 \%$ and $45 \%$ respectively [20]. There were no deaths in our LN group and all patients had preserved renal function at 12 months and $86 \%$ at 51 months of follow up.

Studies have shown a declining eGFR is a risk factor for poor outcome of systemic disease related nephropa- 
thy [2] [21]. We have shown a clear trend of improvement in eGFR in vasculitis patients which correlates with a better renal and overall survival. Compared to results on LN from a single center cohort that showed a progressive decline in eGFR over a long term follow up of 25 years, our study showed a trend to improvement in eGFR in LN patients [22]. This could however be attributed to a shorter period of observation in our study.

The level of proteinuria is associated with the degree of renal scarring and poor long term renal outcome [23]. Reduction in proteinuria is an important measure of favorable response to treatment, particularly in LN [24] [25]. There was a decline in uPCR, a surrogate marker of renal improvement in patients with LN and vasculitis.

During our observation, there were no deaths in either vasculitis or LN groups. This could be attributable to a few factors. First, the period of follow up of 4 years is relatively short as compared to most published studies on patient survival in LN or renal vasculitis [2] [20]-[22] [26]. Second, the numbers of patients were relatively small in both groups. Third in our study observations dated from the first visit to our clinic rather than from the time of diagnosis while most of our comparator groups have studied outcomes from the date of diagnosis.

In summary, our results show better patient renal survival, improvement in eGFR and reduction in uPCR compared to the published studies. Our findings from four years of observation support advocating combined renal rheumatology clinics in managing renal disease from systemic connective tissue disorders.

\section{References}

[1] Willcocks, L., Jones, R. and Jayne, D. (2011) Lupus Nephropathy and Vasculitis. Medicine, 39, 468-491. http://dx.doi.org/10.1016/j.mpmed.2011.05.014

[2] de Joode, A.A., Sanders, J.S. and Stegeman, C.A. (2013) Renal Survival in Proteinase 3 and Myeloperoxidase ANCAAssociated Systemic Vasculitis. Clinical Journal of the American Society of Nephrology: CJASN, 8, 1709-1717. http://dx.doi.org/10.2215/CJN.01020113

[3] Moroni, G., Quaglini, S., Gallelli, B., Banfi, G., Messa, P. and Ponticelli, C. (2013) Progressive Improvement of Patient and Renal Survival and Reduction of Morbidity over Time in Patients with Lupus Nephritis (LN) Followed for 20 Years. Lupus, 22, 810-818. http://dx.doi.org/10.1177/0961203313492576

[4] Langford, C.A. (2010) Vasculitis. The Journal of Allergy and Clinical Immunology, 125, S216-S225. http://dx.doi.org/10.1016/j.jaci.2009.07.002

[5] Saxena, R., Mahajan, T. and Mohan, C. (2011) Lupus Nephritis: Current Update. Arthritis Research \& Therapy, 13, 240. http://dx.doi.org/10.1186/ar3378

[6] Vasculitis and Lupus Service, Addenbrooke’s Hospital, UK. http://www.cuh.org.uk/addenbrookes/services/clinical/vasculitis/vasculitis_lupus_index.html

[7] Ohio State Lupus Clinic, Davis Medical Research Centre, Ohio, USA. http://internalmedicine.osu.edu/rheumatology/patient-care/lupusclinic/

[8] Paediatric Vasculitis Clinic, Monash Children’s Hospital, Australia. https://www.monashchildrenshospital.org/page/About Us/Monash Childrens Services/Paediatric Renal Continence Service/

[9] Kidney International (2012) KDIGO Clinical Practice Guideline for Glomerulonephritis—Chapter 13: Pauci-Immune Focal and Segmental Necrotizing Glomerulonephritis. Kidney Inter, 2, 233-239.

[10] Kidney International (2012) KDIGO Clinical Practice Guideline for Glomerulonephritis_Chapter 12: Lupus Nephritis. Kidney Inter, 2, 221-232.

[11] Bertsias, G.K., Tektonidou, M., Amoura, Z., Aringer, M., Bajema, I., Berden, J.H.M., et al. (2012) Joint European League against Rheumatism and European Renal Association-European Dialysis and Transplant Association (EULAR/ ERA-EDTA) Recommendations for the Management of Adult and Paediatric Lupus Nephritis. Annals of the Rheumatic Diseases, 71, 1771-1782. http://dx.doi.org/10.1136/annrheumdis-2012-201940

[12] Hahn, B.H., McMahon, M.A., Wilkinson, A., Wallace, W.D., Daikh, D.I., FitzGerald, J.D., et al. (2012) American College of Rheumatology Guidelines for Screening, Treatment, and Management of Lupus Nephritis. Arthritis Care \& Research, 64, 797-808. http://dx.doi.org/10.1002/acr.21664

[13] Hiemstra, T.F., Walsh, M., Mahr, A., Savage, C.O., de Groot, K., Harper, L., et al. (2010) Mycophenolate Mofetil vs. Azathioprine for Remission Maintenance in Antineutrophil Cytoplasmic Antibody-Associated Vasculitis: A Randomized Controlled Trial. JAMA: The Journal of the American Medical Association, 304, 2381-2388. http://dx.doi.org/10.1001/jama.2010.1658

[14] Jones, R.B., Tervaert, J.W., Hauser, T., Luqmani, R., Morgan, M.D., Au Peh, C., et al. (2010) Rituximab versus Cyclophosphamide in ANCA-Associated Renal Vasculitis. The New England Journal of Medicine, 363, 211-220. 
http://dx.doi.org/10.1056/NEJMoa0909169

[15] Stone, J.H., Merkel, P.A., Spiera, R., Seo, P., Langford, C.A., Hoffman, G.S., et al. (2010) Rituximab versus Cyclophosphamide for ANCA-Associated Vasculitis. The New England Journal of Medicine, 363, 221-232. http://dx.doi.org/10.1056/NEJMoa0909905

[16] Wall, N. and Harper, L. (2012) Complications of Long-Term Therapy for ANCA-Associated Systemic Vasculitis. Nature Reviews Nephrology, 8, 523-532. http://dx.doi.org/10.1038/nrneph.2012.107

[17] Hahn, B.H., McMahon, M., Wilkinson, A., Dean Wallace, W., Daikh, D.I., FitzGerald, J.D., et al. (2012) American College of Rheumatology Guidelines for Screening, Case Definition, Treatment and Management of Lupus Nephritis. Arthritis Care \& Research, 64, 797-808. http://dx.doi.org/10.1002/acr.21664

[18] Walsh, M., Merkel, P.A., Peh, C.A., Szpirt, W., Guillevin, L., Pusey, C.D., et al. (2013) Plasma Exchange and Glucocorticoid Dosing in the Treatment of Anti-Neutrophil Cytoplasm Antibody Associated Vasculitis (PEXIVAS): Protocol for a Randomized Controlled Trial. Trials, 14, 73. http://dx.doi.org/10.1186/1745-6215-14-73

[19] Flossmann, O., Berden, A., de Groot, K., Hagen, C., Harper, L., Heijl, C., et al. (2011) Long-Term Patient Survival in ANCA-Associated Vasculitis. Annals of the Rheumatic Diseases, 70, 488-494. http://dx.doi.org/10.1136/ard.2010.137778

[20] Zheng, Z., Zhang, L., Liu, W., Lei, Y., Xing, G., Zhang, J., et al. (2012) Predictors of Survival in Chinese Patients with Lupus Nephritis. Lupus, 21, 1049-1056. http://dx.doi.org/10.1177/0961203312445230

[21] Weng, S.C., Tarng, D.C., Chen, C.M., Cheng, C.H., Wu, M.J., Chen, C.H., et al. (2014) Estimated Glomerular Filtration Rate Decline Is a Better Risk Factor for Outcomes of Systemic Disease-Related Nephropathy Than for Outcomes of Primary Renal Diseases. PloS ONE, 9, e92881. http://dx.doi.org/10.1371/journal.pone.0092881

[22] Pokroy-Shapira, E., Gelernter, I. and Molad, Y. (2014) Evolution of Chronic Kidney Disease in Patients with Systemic Lupus Erythematosus over a Long-Period Follow-Up: A Single-Center Inception Cohort Study. Clinical Rheumatology, 33, 649-657. http://dx.doi.org/10.1007/s10067-014-2527-0

[23] Cravedi, P. and Remuzzi, G. (2013) Pathophysiology of Proteinuria and Its Value as an Outcome Measure in Chronic Kidney Disease. British Journal of Clinical Pharmacology, 76, 516-523.

[24] Inker, L.A., Levey, A.S., Pandya, K., Stoycheff, N., Okparavero, A. and Greene, T. (2014) Early Change in Proteinuria as a Surrogate End Point for Kidney Disease Progression: An Individual Patient Meta-Analysis. American Journal of Kidney Diseases: The Official Journal of the National Kidney Foundation, 64, 74-85. http://dx.doi.org/10.1053/j.ajkd.2014.02.020

[25] Korbet, S.M., Lewis, E.J., Schwartz, M.M., Reichlin, M., Evans, J. and Rohde, R.D., Lupus Nephritis Collaborative Study Group (2000) Factors Predictive of Outcome in Severe Lupus Nephritis. American Journal of Kidney Diseases: The Official Journal of the National Kidney Foundation, 35, 904-914. http://dx.doi.org/10.1016/S0272-6386(00)70262-9

[26] Mok, C.C., Kwok, R.C. and Yip, P.S. (2013) Effect of Renal Disease on the Standardized Mortality Ratio and Life Expectancy of Patients with Systemic Lupus Erythematosus. Arthritis and Rheumatism, 65, 2154-2160. http://dx.doi.org/10.1002/art.38006 